\title{
Correlation between acidic ninhydrin and HPLC methods to evaluate fraudulent addition of whey in milk
}

\author{
Sandra Pereira FUKUDA ${ }^{\mathrm{a}}$, Salvador Massaguer ROIG ${ }^{\mathrm{b} *}$, Luiz Francisco PRATA ${ }^{\mathrm{c}}$ \\ ${ }^{\text {a }}$ Dept. de Inspeção de Produtos de Origem Animal - Ministério da Agricultura, Pecuária e Abastecimento \\ do Brasil, Caixa Postal 125, 14 780-970 Barretos, São Paulo, Brasil \\ b Dept. de Tecnologia de Alimentos - Fac. de Eng. de Alimentos - Univ. Est. de Campinas, \\ Caixa Postal 6121, 13083-970 Campinas, São Paulo, Brasil \\ ${ }^{c}$ Dept. de Medicina Veterinária Preventiva - Fac. C. Agr. e Vet. - Univ. Est. Paulista, \\ Via de acesso Prof. Paulo Donato Castellane s/n. ${ }^{\circ}$ 14887-900 Jaboticabal, São Paulo, Brasil
}

Received 2 September 2003 - Accepted 2 April 2004

Published online 4 August 2004

\begin{abstract}
The acidic ninhydrin spectrophotometric method (ANSM) for quantitative determination of free and bound sialic acid of milk glycoprotein has been proved to be fast and efficient for routine detection of fraudulent addition of rennet whey to fluid milk. In this research the ANSM was compared with the high performance liquid chromatography (HPLC) method, internationally recommended for caseinomacropeptide (CMP) determination, which besides its high accuracy is more sophisticated and requires trained personnel. For several sample conditions (raw milk and milk with variable added amounts of rennet cheese whey), the methods showed an excellent linear correlation, with $r=0.981$ when milk was deproteinized with a $120 \mathrm{~g} \cdot \mathrm{L}^{-1}$ final concentration of trichloroacetic acid (TCA) concentration. The best correlations could be seen with final concentrations of $100 \mathrm{~g} \cdot \mathrm{L}^{-1}$ and $80 \mathrm{~g} \cdot \mathrm{L}^{-1} \mathrm{TCA}$; respectively, $r=0.992$ and 0.993 .
\end{abstract}

Milk / adulteration / whey / addition / acidic ninhydrin / HPLC

Résumé - Détection de l'addition frauduleuse de lactosérum au lait de consommation : comparaison de la méthode à la ninhydrine acide (détermination de l'acide sialique) avec la méthode HPLC de détermination du CMP. La méthode spectrophotométrique à la ninhydrine acide (ANSM : acidic ninhydrin spectrophotometric method) pour la détermination des formes libres et liées de l'acide sialique s'est avérée être rapide et performante pour la détection en routine de l'addition frauduleuse de lactosérum doux dans le lait de consommation. Dans l'étude réalisée, l'ANSM a été comparée avec la méthode recommandée au niveau international, à savoir la méthode de détermination du caséinomacropeptide (CMP) par HPLC qui est certes très précise mais requiert un équipement sophistiqué et du personnel hautement qualifié. Une excellente corrélation linéaire a été trouvée entre les deux méthodes lors de l'analyse de filtrats TCA (acide trichloroacétique) issus d'échantillons de lait cru additionnés de quantités variables de lactosérum doux soumis préalablement à un traitement thermique. Selon la concentration finale en TCA : $120 \mathrm{~g} \cdot \mathrm{L}^{-1}, 100 \mathrm{~g} \cdot \mathrm{L}^{-1}$, $80 \mathrm{~g} \cdot \mathrm{L}^{-1}$, les valeurs de corrélation linéaire atteignaient respectivement $0,981,0,992$ et 0,993 .

\section{Lait / fraude / lactosérum / addition / ninhydrine acide / HPLC}

\footnotetext{
* Corresponding author: salvador@fea.unicamp.br
} 


\section{INTRODUCTION}

The $\kappa$-casein, one of the casein fractions of milk, is found in the casein micelles, which are spherical complex structures containing $920 \mathrm{~g} \cdot \mathrm{kg}^{-1}$ of protein and $80 \mathrm{~g} \cdot \mathrm{kg}^{-1}$ of inorganic salts, mainly calcium phosphate, with a porous structure and linked by calcium phosphocaseinate. Currently, one accepted micellar model states that micelles consist of smaller submicelles and that the content of $\kappa$-casein in the submicelles varies, as the submicelles lacking in $\kappa$-casein are located inside of the micelles while the submicelles rich in $\kappa$-casein are concentrated on the surface, giving the micelles a layer rich in $\kappa$-casein. This model proposes that the hydrophilic region $\mathrm{C}$-terminal of the $\mathrm{\kappa}$-casein is projected toward the surface, giving the micelles a hairy appearance. This hairy layer is responsible for the stability of the micelle and once it is removed, the colloidal stability of the micelles is destroyed and milk coagulates or precipitates. The caseins are very susceptible to proteolysis because they contain random structures with little space organization, represented by a small amount of secondary structures of helical type $[2,9$, $10]$.

The $\kappa$-casein, with a minimum molecular weight of $19000 \mathrm{~g} \cdot \mathrm{mol}^{-1}$ and 169 residues of amino acids, is a phosphoprotein containing $60-100 \mathrm{~g} \cdot \mathrm{kg}^{-1}$ of carbohydrates approximately, consisting of N-acetyl-Neuraminic Acid (NANA or sialic acid), galactosyl and $\mathrm{N}$-acetylgalactosamine $[16,17]$. It is the fraction of the caseins not sensitive to calcium and, in normal conditions, carries out an important role in the stability of the micelle, preventing the precipitation of the $\alpha_{\mathrm{s}}$-and $\beta$-casein, when this ion is present [18]. This stabilizing property is lost during enzymatic rennet milk coagulation when only the $\kappa$-casein is hydrolyzed specifically in the cleavage of the amino acids $\mathrm{Phe}_{105^{-}}$ Met $_{106}$. This bond site is much more susceptible to hydrolysis by acid proteinases, such as the commercial rennets, than those of the proteic system of the milk [3].
In the initial cleavage by the rennin's action, there is the formation of two peptides, one composed of the residues of amino acids 1 to 105 , named para- $\kappa$-casein, and another by the residues 106 to 169 , that contains all the sugars of the $\kappa$-casein, named glycomacropeptide or GMP. The $\kappa$-casein is heterogeneous and contains 2 genetic variants, $\mathrm{A}$ and $\mathrm{B}$. The content of carbohydrates in the molecule varies from 0 to $15 \%$ and there is the possibility of obtaining fragments with the absence of carbohydrate. In this case, the terminal peptide is named macropeptide or caseinomacropeptide (CMP), and both (CMP and GMP) remain soluble on the whey and are separated from the curd during cheese production $[8,18]$.

One of the methods of monitoring coagulation action based on $\kappa$-casein is the determination of sialic acid content in cheese whey, a specific indicator of the liberation of GMP [10].

Van Hooydonk and Olieman [19] described High Performance Liquid Chromatography (HPLC) as a fast and sensitive method to monitor the action of the chymosin in milk. In 1983, Olieman and van den Beden [14] used this method to detect and estimate, in skimmed powdered milk, the presence of solids of serum of milk obtained by the action of the rennin.

The composition variability in the glycosidic fraction is responsible for CMP solubility variations in TCA. The macropeptide soluble in $20 \mathrm{~g} \cdot \mathrm{L}^{-1}$ of TCA refers to CMP that includes all the glycosidic forms and, eventually, also the non-glycosylated forms, if present, while the macropeptide soluble in $120 \mathrm{~g} \cdot \mathrm{L}^{-1}$ of TCA refers to those that contain the total carbohydrate of the $\kappa$-casein named GMP [11].

Macropeptide evaluation made by HPLC or Fast Performance Liquid Chromatography (FPLC) depends on the removal of the other proteins using TCA [11]. For van Hooydonk and Olieman [19], the best final concentration, to prevent interfering factors in the determination of GMP through the chromatography methodology, is $80 \mathrm{~g} \cdot \mathrm{L}^{-1}$ of 
TCA, in which the cheese whey proteins are virtually absent. Low concentrations of TCA result in insufficient removal of the whey proteins, while high concentrations cause precipitation of larger amounts of GMP.

The European Union, concerned with the fraudulent addition of whey to the skimmed powder milk destined for public stockpiling, made official through the Regulation of the EU Commission n ${ }^{\circ} 213 / 1981$ the HPLC method for GMP determination and the calorimetric method with resorcinol reagent for sialic acid detection as methods for the identification of this economic adulteration, methodologies that are still accepted today [1].

In Brazil, the Ministry of Agriculture established, in 1991 [12], two official analytical methods of rennet whey detection in milk, a quantitative method for the determination of GMP through the technique of HPLC, and a qualitative method, based on the research of sialic acid adapted by Wolfschoon-Pombo and Pinto, using Ehrlich reagent [20].

In 1994, Fukuda [4] adapted the application to milk of a technique described by Yao et al. [21] for the determination of the concentration of sialic acid in sialoglycoprotein in ascitic liquid formed from abdominal tumors, using acidic ninhydrin as chromophor (Gaitonde Reagent 2).

In that same year, Fukuda et al. [5] proposed the standardization of the spectrophotometric $(470 \mathrm{~nm})$ acidic ninhydrin method for quantitative determination of sialic acid (N-acetyl-Neuraminic Acid-NANA); free, or linked to the glycoprotein in fluid milk and rennet whey. The method was shown to be precise, accurate and sensitive to variations around $2 \%$. Besides these characteristics, the method could be performed easily and with good possibility of use in routine application, since it did not require sophisticated equipment or qualified personnel, and also required less time to execute when compared with other methodologies.
The determination of GMP by the acidic ninhydrin reaction standardized by Fukuda et al. [5] used a $120 \mathrm{~g} \cdot \mathrm{L}^{-1}$ TCA final concentration, with the objective of working only with the glycosylated forms and free from possible interfering factors. On the other hand, the HPLC technique uses an $80 \mathrm{~g} \cdot \mathrm{L}^{-1}$ TCA final concentration in order to search for all the forms of CMP [19].

Based on the results obtained, Fukuda et al. [6] proposed the use of this method as a screening test of the milk received by the dairy plants to detect possible milk adulteration by whey addition. This proposal classified the milk as negative (absorbance at $470 \mathrm{~nm} \leq 0.300$ or $\leq 5.14 \mu \mathrm{g}$ free sialic acid. $\mathrm{mL}^{-1}$ of milk), suspect (absorbance at $470 \mathrm{~nm}$ between 0.300 and 0.600 or between 5.14 and $10.64 \mu \mathrm{g}$ free sialic acid $\cdot \mathrm{mL}^{-1}$ of milk) or positive (absorbance at $470 \mathrm{~nm}>0.600$ or $>10.64 \mu \mathrm{g}$ free sialic acid. $\mathrm{mL}^{-1}$ of milk).

Recently, Furlanetti and Prata [7] studied the variability of the free and total GMP content (after milk sample coagulation with commercial rennet) in bovine milk during lactation, using the method of the acidic ninhydrin reaction standardized by Fukuda et al. [5], and concluded that free and total GMP vary according to the period of lactation and the sanitary conditions of the udder and that it is inversely proportional to the cow's milk production. The free GMP content is higher when close to the colostral period and during the end of the lactation period, while GMP liberated by the rennin shows a similar behavior; however, the content is ten times higher than free GMP.

Prata [15], working with a larger number of samples, confirmed the acidic ninhydrin reaction method as being efficient in fraud detection of whey addition to milk, and suggested altering the values proposed by Fukuda et al. [6] to: $\mathrm{A}_{470 \mathrm{~nm}} \leq 0.300$ or $\leq 5.14 \mathrm{mg}$ free sialic acid. $\mathrm{L}^{-1}$ of milk for the negative category; $0.300<\mathrm{A}_{470 \mathrm{~nm}}<0.450$ or 5.14 to $7.89 \mathrm{mg}$ free sialic acid. $\mathrm{L}^{-1}$ of milk for the suspect category and $\mathrm{A}_{470 \mathrm{~nm}} \geq$ 0.451 or $>7.89 \mathrm{mg}$ free sialic acid. $\mathrm{L}^{-1}$ of milk for the positive category. 
In April 2003, the technique of acidic ninhydrin reaction for the quantitative determination of sialic acid was approved by the Brazilian Ministry of Agriculture as an official method, published through the Normative Instruction $n^{\circ} 22$ [13].

The purpose of this work was to verify the correlation of the acidic ninhydrin and the HPLC methods in the detection of rennet whey added to milk using raw milk samples and raw milk with intentionally added rennet whey samples, in different proportions, and also the influence of the use of TCA concentrations of 80,100 and $120 \mathrm{~g} \cdot \mathrm{L}^{-1}$.

\section{MATERIALS AND METHODS}

Raw milk samples of known origins were obtained over 2 months in dairy plants of the District of Barretos, Sao Paulo State, Brazil. They represented a pool of several producers. Rennet cheese whey from cheese plants from this same region was used, which was heated at $80^{\circ} \mathrm{C}$ for $15 \mathrm{~min}$ in a water-bath after curd separation, for enzymatic inactivation, and after this, it was chilled in ice. All of the milk and whey samples were stored in thermal boxes with ice until arriving at the laboratory. The whey not used on the day of production was frozen.

Adulterated milk samples were prepared by addition of 25 to $600 \mathrm{~mL} \cdot \mathrm{L}^{-1}$ rennet whey to raw milk. Raw milk samples and adulterated milk samples were frozen $\left(-14^{\circ} \mathrm{C}\right)$ until they were submitted to chromatography. During all the determinations samples of raw milk or of adulterated raw milk were performed in duplicate.

To obtain equidistant points that allowed comparisons at a large interval of variations, the addition of different amounts of rennet whey to milk samples was necessary, with the content of GMP previously determined through the acidic ninhydrin method. Six series of experiments were performed.

All the acidic ninhydrin method determinations were realized with 80,100 and $120 \mathrm{~g} \cdot \mathrm{L}^{-1}$ TCA final concentrations, and for the HPLC an $80 \mathrm{~g} \cdot \mathrm{L}^{-1}$ TCA final concentration was used.

The results were submitted to linear regression, to obtain the equation of the straight line and the values of the correlation coefficient $(r)$ and of determination $\left(r^{2}\right)$.

\subsection{Analytical methodologies}

\subsubsection{The acidic ninhydrin method}

Ten mL of milk were mixed with $10 \mathrm{~mL}$ of a $240 \mathrm{~g} \cdot \mathrm{L}^{-1} \mathrm{TCA}$ solution. After the mixture had been standing for $30 \mathrm{~min}$, the precipitate was filtered off. Then, $10 \mathrm{~mL}$ of filtrate were placed in centrifuge tubes, and $1 \mathrm{~mL}$ of a $200 \mathrm{~g} \cdot \mathrm{L}^{-1}$ phosphotungstic acid solution was added. After centrifugation (3500 rpm for $10 \mathrm{~min}$ ), the supernatant was gently discarded and the sediment dispersed with $6 \mathrm{~mL}$ of $950 \mathrm{~mL} \cdot \mathrm{L}^{-1}$ ethyl alcohol. Another centrifugation was carried out for $10 \mathrm{~min}$ and the supernatant was gently discarded again. Then $2 \mathrm{~mL}$ of glacial acetic acid and $1 \mathrm{~mL}$ of acidic ninhydrin reagent (1 $\mathrm{g}$ of ninhydrin, $16 \mathrm{~mL}$ of hydrochloridric acid P.A. and $24 \mathrm{~mL}$ of glacial acetic acid) were added to the residue. After homogenization, the mixture was heated in a strong water-bath for exactly $10 \mathrm{~min}$. There was a color development varying from yellow to brown-yellowish. The solution was chilled in cold water and immediately after it was submitted to a spectrophotometric reading in the wavelength of $470 \mathrm{~nm}$, against the white of the reagents. The readings can be transformed in sialic acid concentration $\left(\mu \mathrm{g} \cdot \mathrm{mL}^{-1}\right.$ of milk), comparing them with a standard curve prepared with sialic acid [4, 5]. For the described method, the final dilution of TCA was $120 \mathrm{~g} \cdot \mathrm{L}^{-1}$.

To achieve the final concentration of $80 \mathrm{~g} \cdot \mathrm{L}^{-1}, 20 \mathrm{~mL}$ of milk and $10 \mathrm{~mL}$ of TCA $240 \mathrm{~g} \cdot \mathrm{L}^{-1}$ were mixed, and for $100 \mathrm{~g} \cdot \mathrm{L}^{-1}$, $14 \mathrm{~mL}$ of milk and $10 \mathrm{~mL}$ of TCA $240 \mathrm{~g} \cdot \mathrm{L}^{-1}$ were used; the other procedures were the same as those already described. 


\subsubsection{HPLC method}

To each $10 \mathrm{~mL}$ of fluid milk $5 \mathrm{~mL}$ of TCA $240 \mathrm{~g} \cdot \mathrm{L}^{-1}$ was added in drips, under constant stirring. After the mixture had been standing for $60 \mathrm{~min}$, the precipitate was filtered off, discarding the first drops. Fifteen to $30 \mu \mathrm{L}$ of the filtrate were submitted to a chromatography reading in HPLC equipment (Hewlett-Packard Co., USA), with manual injection and looping of $100 \mu \mathrm{L}$, a Zorbax Bio Series GF-250 (DuPont Company) column with $9.4 \mathrm{~mm}$ of internal diameter by $25 \mathrm{~cm}$ of length and an integrator-recorder. The flow was $1.0 \mathrm{~mL}$ per minute and the detection happened in the band of the UV-VIS, in the wavelength of $205 \mathrm{~nm}$. The eluent used in the separation was a $\mathrm{pH} 6$ phosphate standard solution with $21.41 \mathrm{~g} \cdot \mathrm{L}^{-1}$ of sodium sulfate added. This solution was filtered through a membrane of $0.45 \mu \mathrm{m}$ and degassed. The standard curve was elaborated using milk of known origin and also through the same milk with 50,100,150 and $200 \mathrm{~g} \cdot \mathrm{L}^{-1}$ of added cheese whey $[13,19]$.

\section{RESULTS AND DISCUSSION}

The results obtained with the acidic ninhydrin method with 80,100 and $120 \mathrm{~g} \cdot \mathrm{L}^{-1}$ TCA final concentrations are presented in Table I. The results obtained with the HPLC method and for the $80 \mathrm{~g} \cdot \mathrm{L}^{-1}$ TCA final concentration are shown in Table II. Results were considered in the acidic ninhydrin method as the value of the absorbance at $470 \mathrm{~nm}$ and for the HPLC, the height of the peaks of the HPLC chromatograms, with a retention time of around $6.8 \mathrm{~min}$.

The variation coefficients of the duplicates in each experiment were satisfactory, always under $10 \%$. The medium value of 0.162 of absorbance to $470 \mathrm{~nm}$ obtained for raw milk (without whey addition) obtained by the acidic ninhydrin method with $120 \mathrm{~g} \cdot \mathrm{L}^{-1}$ of TCA (Tab. II) is within the range of values obtained by Fukuda [4] for authentic raw milk of $0.248 \pm 58.8 \%$.
The percentages of rennet whey added to the milk were correlated with the results obtained by the acidic ninhydrin methodology for each one of the TCA final concentrations used (Figs. 1, 2 and 3). The linear regressions obtained, for a confidence interval of $95 \%$, resulted in values of $r$ of 0.996 , 0.995 and 0.985 , respectively, for the TCA final concentrations of 80,100 and $120 \mathrm{~g} \cdot \mathrm{L}^{-1}$. As can be observed in Figures 1, 2 and 3, the experimental data obtained was in agreement with the Beer's law, where the value of the absorbance for a certain substance is proportional to its concentration, confirming the viability of this methodology for the spectrophotometric determination of the addition of cheese whey to milk.

The $r$ values obtained for ANSM with the three different TCA final concentrations showed a small difference between them. The use of the $80 \mathrm{~g} \cdot \mathrm{L}^{-1}$ TCA concentration presented the best result and represents a reagent economy, rendering a cheaper methodology; it is also the same one recommended by van Hooydonk and Olieman [19], who found it to be the most suitable for the HPLC method. The concentration of $120 \mathrm{~g} \cdot \mathrm{L}^{-1}$ of TCA as described by Fukuda et al. [6] presented a smaller value for $r$.

Figure 4 shows the correlation of the whey addition to the milk with the results obtained by the HPLC method, confirming the proof precision for a $r$ value of 0.999 for a confidence interval of $95 \%$.

The chromatographic analysis (Fig. 5) presented the best correlation index for the four cases; however, the differences between them were small, mainly when comparing HPLC and ANSM with $80 \mathrm{~g} \cdot \mathrm{L}^{-1}$ TCA: respectively, 0.999 and 0.996 .

The values obtained with the spectrophotometric methodology with acidic ninhydrin were correlated with the values obtained with the HPLC methodology (Figs. 6, 7 and 8 ). The $r$ values found, $0.993,0.992$ and 0.981 , respectively, for the TCA final concentrations of 80,100 and $120 \mathrm{~g} \cdot \mathrm{L}^{-1}$, were highly satisfactory, indicating that the first one presented a slightly superior result. 


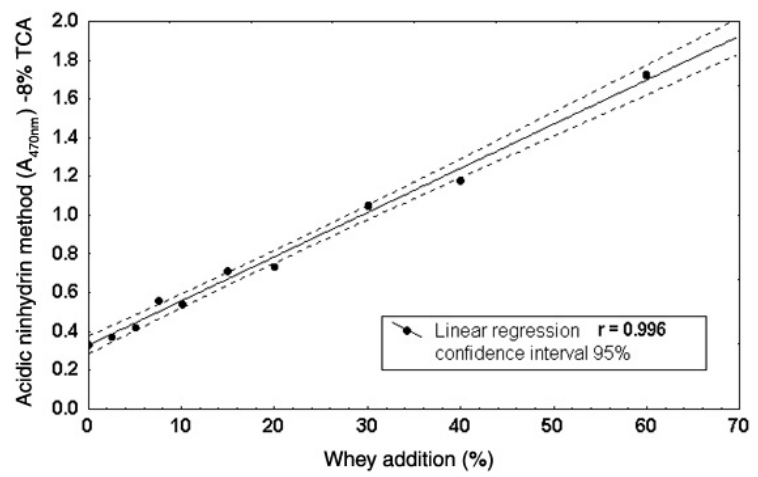

Figure 1. Correlation between rennet whey addition to milk and the results obtained by the acidic ninhydrin method (spectrophotometric determination at $470 \mathrm{~nm}$ ) with the $80 \mathrm{~g} \cdot \mathrm{L}^{-1}$ TCA final concentration.

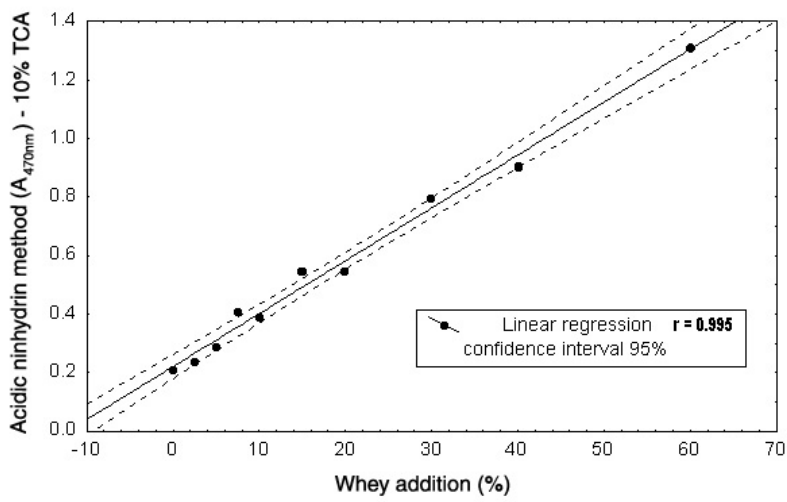

Figure 2. Correlation between rennet whey addition to milk and the results obtained by the acidic ninhydrin method (spectrophotometric determination at $470 \mathrm{~nm}$ ) with the $100 \mathrm{~g} \cdot \mathrm{L}^{-1}$ TCA final concentration.

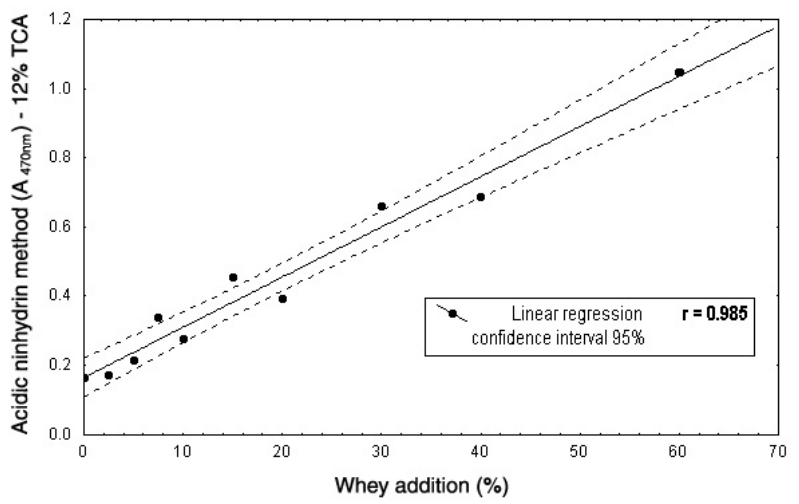

Figure 3. Correlation between rennet whey addition to milk and the results obtained by the acidic ninhydrin method (spectrophotometric determination at $470 \mathrm{~nm}$ ) with the $120 \mathrm{~g} \cdot \mathrm{L}^{-1}$ TCA final concentration. 
Table I. Values obtained with acidic ninhydrin method (absorbance at $470 \mathrm{~nm}$ ) in raw milk samples and rennet whey milk added samples with 80,100 and $120 \mathrm{~g} \cdot \mathrm{L}^{-1}$ trichloroacetic acid (TCA) final concentration.

\begin{tabular}{|c|c|c|c|c|c|c|c|c|c|}
\hline \multirow{3}{*}{$\begin{array}{l}\text { TCA } \\
\mathrm{g} \cdot \mathrm{L}^{-1}\end{array}$} & \multirow{3}{*}{$\begin{array}{c}\text { Whey } \\
\text { addition } \\
\text { g. } \mathrm{L}^{-1}\end{array}$} & \multicolumn{6}{|c|}{ Absorbance at $470 \mathrm{~nm} *$} & \multirow{3}{*}{ Average } & \multirow{3}{*}{$\begin{array}{c}\text { Relative } \\
\text { s.d.** } \\
\%\end{array}$} \\
\hline & & \multicolumn{6}{|c|}{ Experiments } & & \\
\hline & & I & I I & I I I & I V & $\mathrm{V}$ & V I & & \\
\hline \multirow{10}{*}{80} & 0 Raw Milk & 0.386 & 0.254 & 0.316 & 0.307 & 0.355 & 0.353 & 0.328 & \pm 14.1 \\
\hline & 25 & 0.439 & 0.312 & & & & & 0.375 & \pm 23.9 \\
\hline & 50 & 0.475 & 0.336 & 0.435 & 0.428 & & & 0.418 & \pm 14.1 \\
\hline & 75 & & & & & 0.543 & 0.575 & 0.559 & \pm 4.0 \\
\hline & 100 & 0.543 & 0.458 & 0.571 & 0.579 & & & 0.538 & \pm 10.3 \\
\hline & 150 & & & & & 0.762 & 0.664 & 0.713 & \pm 9.7 \\
\hline & 200 & 0.738 & 0.652 & 0.796 & 0.760 & & & 0.736 & \pm 8.3 \\
\hline & 300 & & & & & 1.127 & 0.974 & 1.050 & \pm 10.3 \\
\hline & 400 & & & 1.245 & 1.116 & & & 1.180 & \pm 7.7 \\
\hline & 600 & & & & & 1.875 & 1.576 & 1.725 & \pm 12.2 \\
\hline \multirow{10}{*}{100} & 0 Raw Milk & 0.235 & 0.153 & 0.202 & 0.188 & 0.233 & 0.233 & 0.207 & \pm 15.9 \\
\hline & 25 & 0.272 & 0.205 & & & & & 0.238 & \pm 19.9 \\
\hline & 50 & 0.327 & 0.234 & 0.301 & 0.297 & & & 0.290 & \pm 13.6 \\
\hline & 75 & & & & & 0.405 & 0.411 & 0.408 & \pm 1.0 \\
\hline & 100 & 0.397 & 0.313 & 0.437 & 0.411 & & & 0.389 & \pm 13.8 \\
\hline & 150 & & & & & 0.552 & 0.549 & 0.550 & $\pm \quad 0.4$ \\
\hline & 200 & 0.540 & 0.462 & 0.613 & 0.566 & & & 0.545 & \pm 11.6 \\
\hline & 300 & & & & & 0.834 & 0.756 & 0.795 & \pm 6.9 \\
\hline & 400 & & & 0.917 & 0.891 & & & 0.904 & \pm 2.0 \\
\hline & 600 & & & & & 1.384 & 1.239 & 1.311 & \pm 7.8 \\
\hline \multirow{10}{*}{120} & 0 Raw Milk & 0.183 & 0.112 & 0.151 & 0.164 & 0.169 & 0.192 & 0.162 & \pm 17.5 \\
\hline & 25 & 0.204 & 0.140 & & & & & 0.172 & \pm 26.3 \\
\hline & 50 & 0.240 & 0.164 & 0.229 & 0.237 & & & 0.217 & \pm 16.6 \\
\hline & 75 & & & & & 0.347 & 0.330 & 0.338 & $\pm \quad 3.5$ \\
\hline & 100 & 0.266 & 0.220 & 0.292 & 0.324 & & & 0.275 & \pm 16.0 \\
\hline & 150 & & & & & 0.439 & 0.466 & 0.452 & $\pm \quad 4.2$ \\
\hline & 200 & 0.366 & 0.316 & 0.450 & 0.437 & & & 0.392 & \pm 16.1 \\
\hline & 300 & & & & & 0.709 & 0.608 & 0.658 & \pm 10.8 \\
\hline & 400 & & & 0.685 & 0.695 & & & 0.690 & $\pm \quad 1.0$ \\
\hline & 600 & & & & & 1.103 & 0.996 & 1.049 & $\pm \quad 7.8$ \\
\hline
\end{tabular}

* Average of duplicates; ** standard deviation. 


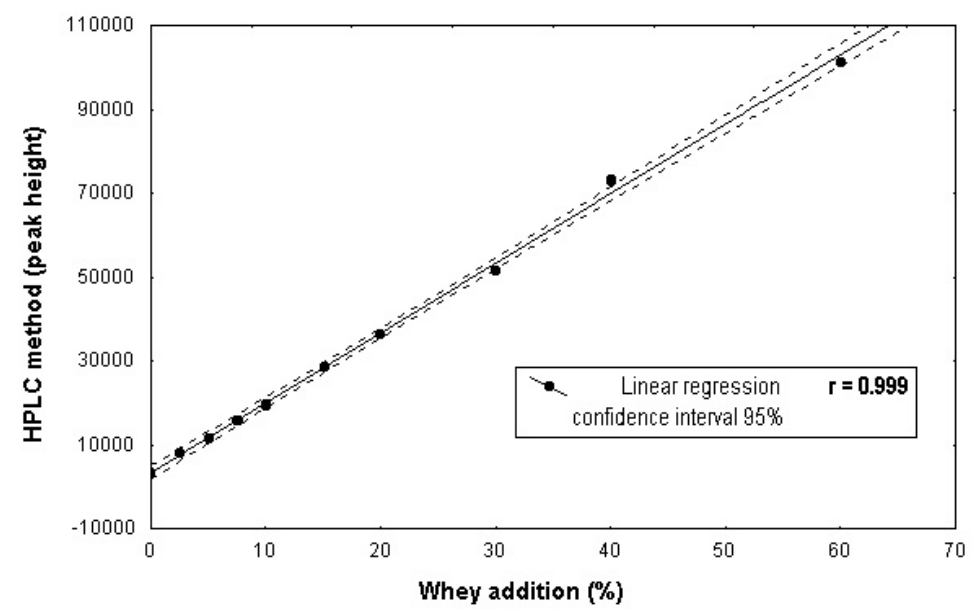

Figure 4. Correlation between rennet whey addition to milk and the results obtained by the HPLC method (height of peaks determination) with the $80 \mathrm{~g} \cdot \mathrm{L}^{-1}$ TCA final concentration.

Table II. Values obtained with high performance liquid chromatography (HPLC) method in raw milk samples and rennet whey milk added samples with $80 \mathrm{~g} \cdot \mathrm{L}^{-1}$ trichloroacetic acid (TCA) final concentration.

\begin{tabular}{|c|c|c|c|c|c|c|c|c|c|}
\hline \multirow{2}{*}{$\begin{array}{l}\text { TCA } \\
\mathrm{g} \cdot \mathrm{L}^{-1}\end{array}$} & \multirow{2}{*}{$\begin{array}{c}\text { Whey } \\
\text { addition } \\
\mathrm{g} \cdot \mathrm{L}^{-1}\end{array}$} & \multicolumn{6}{|c|}{$\begin{array}{l}\text { Absorbance at } 470 \mathrm{~nm} * \\
\text { Experiments }\end{array}$} & \multirow{2}{*}{ Average } & \multirow{2}{*}{$\begin{array}{c}\text { Relative } \\
\text { s.d.** } \\
\%\end{array}$} \\
\hline & & I & I I & II I & I V & $\mathrm{V}$ & V I & & \\
\hline \multirow{10}{*}{80} & 0 Raw Milk & 4767 & 2817 & 2925 & 3179 & 2774 & 3696 & 3359 & \pm 22.9 \\
\hline & 25 & 8266 & 7608 & & & & & 7937 & \pm 5.9 \\
\hline & 50 & 11175 & 12229 & 11686 & 11026 & & & 11529 & $\pm \quad 4.7$ \\
\hline & 75 & & & & & 15400 & 16377 & 15889 & $\pm \quad 4.3$ \\
\hline & 100 & 17107 & 20998 & 20917 & 19311 & & & 19583 & $\pm \quad 9.3$ \\
\hline & 150 & & & & & 26809 & 30276 & 28542 & \pm 8.6 \\
\hline & 200 & 30249 & 40384 & 39167 & 35909 & & & 36427 & \pm 12.4 \\
\hline & 300 & & & & & 50837 & 52401 & 51619 & $\pm \quad 2.1$ \\
\hline & 400 & & & 76569 & 70217 & & & 73393 & \pm 6.1 \\
\hline & 600 & & & & & 105094 & 102095 & 103594 & $\pm \quad 2.0$ \\
\hline
\end{tabular}

* Average of duplicates; $* *$ standard deviation.

This means that all of the variations in the CMP contents detected by the HPLC had a correspondence of high confiability with the content of sialic acid obtained by spec- trophotometry, even considering the results with a smaller correlation index $\left(120 \mathrm{~g} \cdot \mathrm{L}^{-1}\right.$ TCA). It was verified that the determination coefficient between the techniques was $96 \%$ 
a) Milk

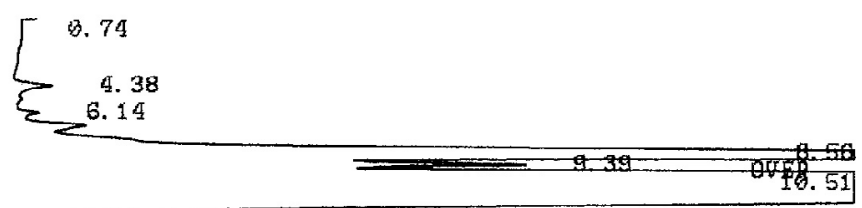

15. 13

b) Milk and 5\% of whey

0.09

4. 38

6. 13

6. 98

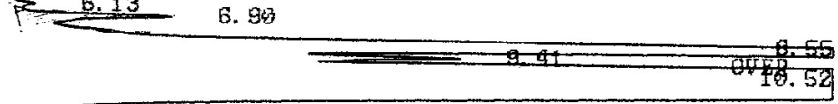

15. 52

c) Milk and $10 \%$ of whey

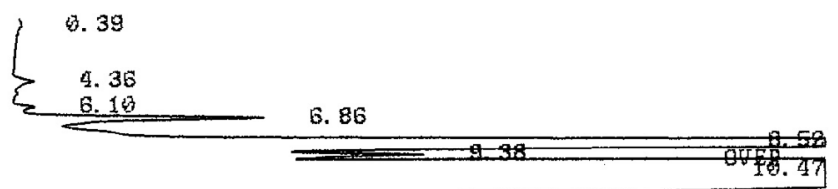

15.52

d) Milk and 20\% of whey

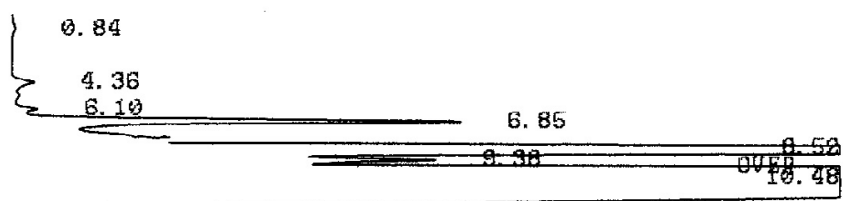

15. 44

Figure 5. Detection of GMP by HPLC of normal milk and with several levels of whey added to milk.

of the results. The equations for the straight $112007.2 \times \mathrm{A}_{470 \mathrm{~nm}}$, respectively, for 80 , line obtained were HPLC $=-20478.9+100$ and $120 \mathrm{~g} \cdot \mathrm{L}^{-1}$ final TCA concentrations. $73033.2 \times \mathrm{A}_{470 \mathrm{~nm}}, \mathrm{HPLC}=-16687.3+\quad$ As milks from different places were used $92024.6 \times \mathrm{A}_{470 \mathrm{~nm}}$ and HPLC $=-14152.2+\quad$ in the many experiments, the correlation 


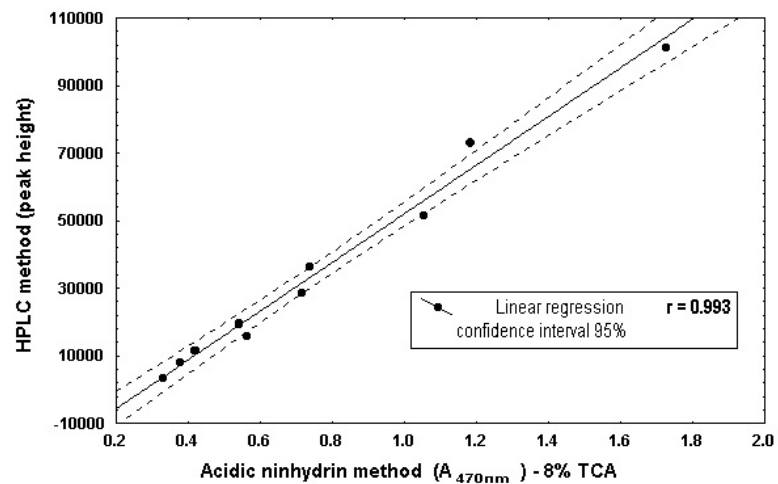

Figure 6. Correlation between the acidic ninhydrin method using the $80 \mathrm{~g} \cdot \mathrm{L}^{-1}$ TCA final concentration and HPLC in the evaluation of rennet whey addition to milk.

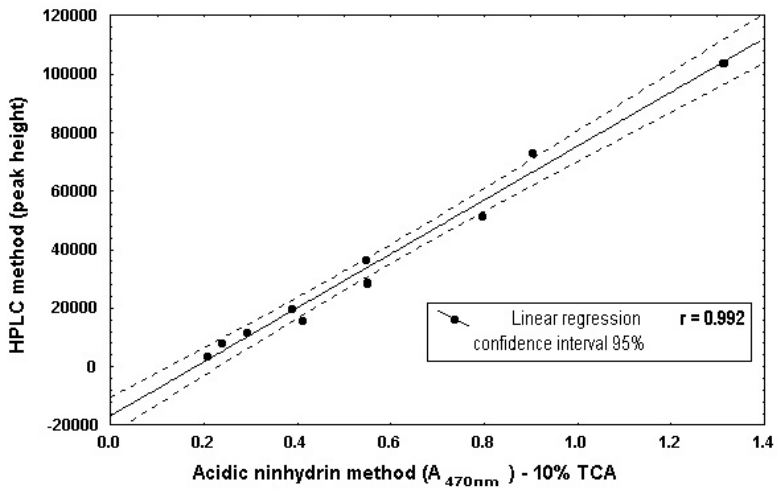

Figure 7. Correlation between the acidic ninhydrin method using the $100 \mathrm{~g} \cdot \mathrm{L}^{-1} \mathrm{TCA}$ final concentration and HPLC in the evaluation of rennet whey addition to milk.

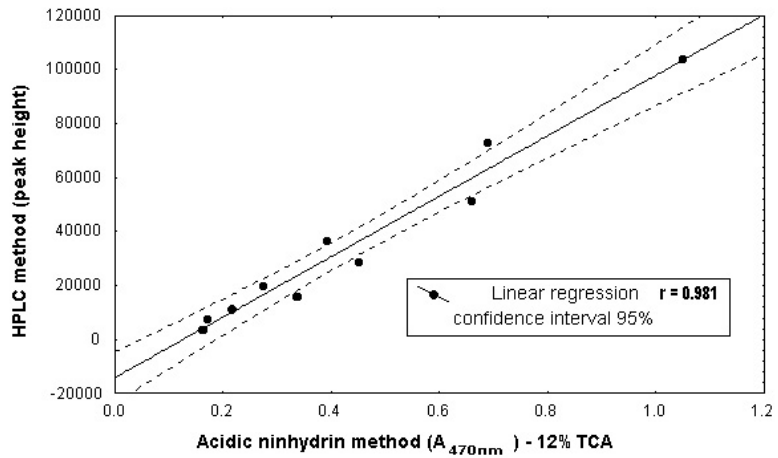

Figure 8. Correlation between the acidic ninhydrin method using the $120 \mathrm{~g} \cdot \mathrm{L}^{-1} \mathrm{TCA}$ final concentration and HPLC in the evaluation of rennet whey addition to milk. 
between the two methodologies can be considered quite reliable, even considering the observations of Guinee and Wilkinson [8] concerning the heterogeneity of the $\kappa$-casein, its 2 genetic variants, $A$ and $B$, and the content of carbohydrates in the molecule, that can vary by up to $15 \%$.

For developing countries of continental dimensions, where sample remittance to the government network of laboratories is difficult, and where there are not always enough laboratories to meet the demand, the acidic ninhydrin methodology can be used as "screening" methodology by the government's milk industry control services. Other methods, such as HPLC and imported kits from other countries for determination of sialic acid, are either expensive and/or require specialized personnel to set up and perform such methods.

\section{CONCLUSION}

The results obtained in this experiment allow us to conclude that the acidic ninhydrin method can be considered either as a screening methodology or as a substitute for HPLC methodology for the detection of whey addition to milk, leaving the HPLC, an onerous process that demands qualified personnel, for the doubtful cases or doublechecking proofs.

The results obtained with the spectrophotometric methodology also allow us to suggest the modification of the Fukuda [4] methodology for a final TCA concentration of $80 \mathrm{~g} \cdot \mathrm{L}^{-1}$.

Acknowledgements: The authors are grateful to the Milk Inspection Service of the Ministry of Agriculture, Livestock and Supply of Brazil and to the Animal Reference Laboratory of Pedro Leopoldo/MG.

\section{REFERENCES}

[1] Commission Regulation (EC), J. Commun. Eur. $n^{\circ} 213 \mathrm{~L}$ (2001) pp. 1-99.
[2] Cromie S., Psychrotrophs and their enzyme residues in cheese milk, Aust. J. Dairy Technol. 47 (1992) 96-100.

[3] Fox P.F., Proteolysis during cheese manufacture and ripening, J. Dairy Sci. 72 (1989) 1370-1400.

[4] Fukuda S.P., Estudo de metodologia quantitativa para determinação espectrofotométrica de ácido siálico em leite. Dissertação Faculdade de Engenharia de Alimentos, Universidade Estadual de Campinas, SP, Brasil, 1994.

[5] Fukuda S.P., Roig S.M., Prata L.F., Metodologia quantitativa para determinação espectrofotométrica de ácido siálico em leite, in: Anais do XII Congresso Nacional de Laticínios, Juiz de Fora, MG, Brasil, 1994, pp. 114 119.

[6] Fukuda S.P., Roig S.M., Prata L.F., Aplicação do método da ninidrina ácida como teste de "screening" de plataforma para a detecção da adição de soro ao leite, Ciênc. Tecnol. Alim. 16 (1996) 52-56.

[7] Furlanetti A., Prata L.F., Free and total GMP (glyco-macropeptide) contents of milk during bovine lactation, Ciênc. Tecnol. Alim. 23 (Suppl.) (2003) 121-125.

[8] Guinee T.P., Wilkinson M.G., Rennet coagulation and coagulants in cheese manufacture, J. Soc. Dairy Technol. 45 (1992) 94-104.

[9] Holt C., Structure and stability of bovine casein micelles, Adv. Protein Chem. 43 (1992) 63151.

[10] Léonil J., Mollé D., A method for determination of macropeptide by cation-exchange fast protein liquid chromatography and its use for following the action of chymosin in milk, $\mathrm{J}$. Dairy Res. 58 (1991) 321-328.

[11] Leske B., Konrad G., A new method to estimate caseinomacropeptide and glycomacropeptide from trichloroacetic acid filtrates, Milchwissenschaft 51 (1996) 431-435.

[12] Ministério da Agricultura e Reforma Agrária do Brasil, Portaria n ${ }^{\circ}$ 124, 23 set.1991, Aprova métodos analíticos qualitativo e quantitativo de detecção de soro em leite, Diário Oficial da União, 20 nov. 1991, pp. 26245-26246.

[13] Ministério da Agricultura, Pecuária e Abastecimento do Brasil, Instrução Normativa da Secretaria de Defesa Agropecuária $\mathrm{n}^{\circ}$ 22, 14 abr. 2003, Oficializa métodos analíticos físico-químicos para controle de leite e produtos lácteos, Diário Oficial da União, 02 mai. 2003, pp.3-25.

[14] Olieman C., van den Beden J.W., A sensitive HPLC method of detecting and estimating rennet whey total solids in skim milk powder, Neth. Milk Dairy J. 37 (1983) 27-36. 
[15] Prata L.F., Distribuição de GMP livre, em leites crus e pasteurizados, na definição da detecção de fraudes por adição de soro, Thesis, Faculdade de Ciências Agrárias e Veterinárias, UNESP, Jaboticabal, SP, Brasil, 2002.

[16] Saito T., Itoh T., Variations and distributions of O-glycosidally linked sugar chains in bovine K-casein, J. Dairy Sci. 75 (1992) 1768-1774.

[17] Schimidt D.G., Colloidal aspects of casein, Neth. Milk Dairy J. 34 (1980) 42-64.

[18] Shammet K.M., Brown R.J., McMahon D.J., Proteolytic activity of some milk-clotting enzymes on K-casein, J. Dairy Sci. 75 (1992) 1373-1379.
[19] Van Hooydonk A.C.M., Olieman C., A rapid and sensitive high-performance liquid chromatography method of following the action of chymosin in milk, Neth. Milk Dairy J. 36 (1982) 153-158.

[20] Wolfschoon-Pombo A.F., Pinto A.P.E.F., A qualitative method for the detection of rennet whey in milk, Ciênc. Tecnol. Alim. 5 (1985) 111-115.

[21] Yao K., Ubuka T., Masuoka N., Kinuta M., Ikeda T., Direct determination of bound sialic acids in sialoglycoproteins by acidic ninhydrin reaction, Anal. Biochem. 179 (1989) 332-335. 